\section{Water-efficient Urban Landscapes: Integrating Different Water Use Categorizations and Plant Types}

\author{
Hongyan Sun, Kelly Kopp ${ }^{1}$, and Roger Kjelgren \\ Department of Plants, Soils, and Climate, Utah State University, 4820 Old \\ Main Hill, Logan, UT 84322
}

Additional index words. water conservation, urban landscape, soil water content, water balance, canopy cover, plant factor $\left(\mathrm{K}_{\mathrm{p}}\right)$, landscape factor $\left(\mathrm{K}_{1}\right)$

\begin{abstract}
Little research has examined water requirements of entire irrigated urban landscapes integrating different types of plants. Three landscape treatments integrating different types of plants-woody, herbaceous perennial, turf-and putative water use classifications-mesic, mixed, xeric - were grown in large drainage lysimeters. Each landscape plot was divided into woody plant, turf, and perennial hydrozones and irrigated for optimum water status over 2 years and water use measured using a water balance approach. For woody plants and herbaceous perennials, canopy cover rather than plant type or water use classification was the key determinant of water use relative to reference evapotranspiration (ET $\mathbf{T}_{\mathrm{o}}$ ) under well-watered conditions. For turf, monthly evapotranspiration $\left(\mathbf{E T}_{\mathrm{a}}\right)$ followed a trend linearly related to $\mathbf{E T}_{\mathbf{0}}$. Monthly plant factors $\left(K_{p}\right)$ for woody plants, perennials, and turf species under well-watered conditions in this study ranged from 0.3 to $0.9,0.2$ to 0.5 , and 0.5 to 1.2, respectively. Adjusted $K_{p}$ for each hydrozone was calculated based on landscaped area covered by plant types as a percent of total area, and landscape factor $\left(K_{l}\right)$ was calculated based on adjusted $K_{p}$ for each landscape treatment. Overall, $K_{1}$ relative to $\mathrm{ET}_{\mathrm{o}}$ ranged from 0.6 to 0.8 for three water use classifications.
\end{abstract}

Drought and rapid population growth strain urban water supplies throughout the urbanizing Intermountain West (IMW). Irrigated urban landscapes are the largest use of municipal water resources and can consume $\approx 60 \%$ of potable municipal water in the region (Kjelgren et al., 2000; Utah Division of Water Resources, 2003). Because it is a limited resource in the IMW, efficient water use in irrigated urban landscapes is a fundamental long-term conservation policy for managing increasing demand and limited and uncertain supplies (St. Hilaire et al., 2008).

Xeriscaping, low water use landscaping, and water efficient landscaping are key water conservation approaches promoted in periodically water-deficit regions of the United States (Smith and St. Hilaire, 1999). In practice, these techniques are generally synonymous and refer to landscaping specifically designed to reduce water use relative to uniform turfgrass landscapes (St. Hilaire et al., 2008). For simplicity, this study will use the term water-efficient landscaping to include mindful design, efficient irrigation systems, appropriate turf areas, appropriate plant material (turf and non-turf)

Received for publication 7 Sept. 2011. Accepted for publication 9 Dec. 2011.

Utah Agricultural Experiment Station Number 8402. Mention of a trademark, proprietary product, or vendor does not constitute a guarantee or warranty of the product by the ASHS and does not imply its approval to the exclusion of other products or vendors that also may be suitable.

${ }^{1}$ To whom reprint requests should be addressed; e-mail kelly.kopp@usu.edu. choices, improved soil, mulching, and strategic maintenance.

Water-efficient landscaping can reduce water consumption without compromising landscape functionality or aesthetics (St. Hilaire et al., 2008). However, little research has quantified water needs of water-efficient landscapes compared with traditional landscapes, particularly regarding plant material. One 5-year study in Las Vegas, NV, showed single-family homes with water-efficient landscapes used $76 \%$ less water than turfgrass landscapes (Sovocool et al., 2006). However, those results were taken from a survey of voluntary participants such that traditional and water-efficient landscapes differed in many ways, including planting design, irrigation systems, and plant material. Because most water-efficient landscaping principles apart from plant material can be applied to any landscape, impact of plant selection alone is of research interest.

Plant water use characteristics inform designers, managers, and policymakers vested in water-efficient landscapes. These stakeholders require information that allows estimation of minimum plant water demand that balances atmospheric evaporative pressure with visual, functional, and health performance expectations (Shaw and Pittenger, 2004; White et al., 2004). The existing approach to estimating urban landscape irrigation water use is derived from agriculture. The American Society of Civil Engineers Penman-Monteith (ASCE-PM) reference $\mathrm{ET}_{\mathrm{o}}$ equation is the simplified and accepted standard reference in agricultural settings for estimating plant water use with no soil water limits (Allen et al., 2005a).
The ASCE-PM can model water used by a hypothetical reference short, cool-season grass surface based on inputs of local wind, air temperature, humidity, and incoming shortwave solar radiation. Calculated $\mathrm{ET}_{\mathrm{o}}$ is then corrected (for crops, typically but not always downward) with an empirical species-specific correction coefficient $\left(\mathrm{K}_{\mathrm{c}}\right)$ that is a fraction of $\mathrm{ET}_{\mathrm{o}}$ such that:

$$
\mathrm{ET}_{\mathrm{c}}=\mathrm{ET}_{\mathrm{o}} \times \mathrm{K}_{\mathrm{c}}
$$

where $\mathrm{ET}_{\mathrm{c}}$, is estimated plant water use proportional to irrigation water requirements for optimum, quantitative yield of a target crop. Eq. 1 assumes vertical water movement controlled by stomatal opening and wind from a large, uniform crop surface, mirroring underlying assumptions, and thus a linear function, of $\mathrm{ET}_{\mathrm{o}}$ (Bos et al., 2008).

Many of these assumptions do not translate well to urban landscapes. Sufficient urban fetch and solar exposure for calculating $\mathrm{ET}_{\mathrm{o}}$ for a uniform plant surface complicate and limit weather station site selection (Eching and Snyder, 2005). Ideal urban weather station sites with a uniform plant surface are then at odds with the non-uniformity, small size, and ventilated roughness characteristics of urban landscapes. Moreover, plants in urban landscapes are diverse architectural types - trees, shrubs, perennials, turfgrassmanifesting a wide range of water use characteristics. Furthermore, urban landscape plants succeed when meeting appearance expectations rather than yielding a quantitative product. Biophysical diversity and appearance expectations suggest minimum water needs in a water-efficient landscape are a subjective threshold rather than an objective target (Shaw and Pittenger, 2004). This threshold is potentially much lower than what plants would use with unlimited water supply and may be achieved even when plants are water-limited or stressed. Consequently, a plant factor, $K_{p}$ (Eching and Snyder 2005; EPA WaterSense, 2009), rather than a coefficient $K_{c}$, more candidly represents the attenuated relationship between heterogenous urban landscape biophysical water use and homogenous urban $\mathrm{ET}_{\mathrm{o}} . \mathrm{A} \mathrm{K}_{\mathrm{p}}$ can characterize minimum water needs of general landscape plant typeswoody and herbaceous - but can be speciesspecific for the few commonly used turfgrass species, because turf $\mathrm{K}_{\mathrm{p}}$ may be equal to $\mathrm{K}_{\mathrm{c}}$ when grasses are well-watered and obtain optimum growth and development.

Species complexity in distinguishing minimum plant needs from maximum, well-watered use constrains development of landscape $K_{p}$ values useful to water-efficient landscape stakeholders. Well-watered $\mathrm{K}_{\mathrm{p}}$ values for warm- and cool-season turfgrass species have been reasonably well characterized (Aronson et al., 1987; Carrow, 1995; Fry and Butler, 1989; Kopec et al., 1988), but minimum turfgrass water requirements have not. Plant factors have been reported for a number of landscape (tree, shrubs, herbaceous) species under well-watered (Beeson, 2005; Montague et al., 2004; Pannkuk et al., 2010) and minimum, water-limited conditions (Pittenger and 
Henry, 2005; Reid and Oki, 2008; Shaw and Pittenger, 2004). These reports cover a small percentage of the total number of possible landscape plants and how $\mathrm{K}_{\mathrm{p}}$ values developed in one climate translate to a different climate is problematic (Kjelgren et al., 2005).

Further complicating water-efficient landscape water needs estimation, scaling an assemblage of $K_{p}$ values up to part of or the entire urban landscape is an increasingly necessary but conceptually muddled process. Increasing use of $\mathrm{ET}_{\mathrm{o}}$-based smart controllers demands input of a $K_{p}$ for turf and typically mixed species landscape plants for setting irrigation schedules at the individual irrigation zone level. Policy needs for allocating a fixed amount of water to end users demands a $K_{p}$ over an entire landscape (often referenced as $\mathrm{K}_{1}$; see Costello et al., 2000) for setting water allocation at the policy level. Theoretical approaches to zone level or landscape level have suggested assigning $\mathrm{K}$ values grouped by plant types (tree, shrub, perennial, turf; EPA WaterSense, 2009; Water Use Efficiency Branch, 2009) or water use categorization (high-medium-low; Costello et al., 2000), each with various factors to correct for climate, plant density, and sometimes water stress (Bos et al., 2008; Eching and Snyder, 2005). However, there are little empirical data validating grouping of minimum water needs by plant type, water use categorization, or various correction factors (see Devitt and Morris, 2008; Pannkuk et al., 2010; Sachs et al., 1975).

Consequently, empirical data are needed to distinguish plant water use of different plant types and water use categorizations. This research was conducted under well-watered conditions in designed landscapes comprised of plant types such as turf, perennials, and woody plants. Once established, minimum water-efficient landscape water needs under water-limiting conditions may then be more clearly defined. Objectives of this study were to develop water balances for water-efficient landscapes with no soil water limits consisting of three putative water use characterizationsmesic, mixed and xeric - and plant material of three different types - woody, herbaceous perennial, and turf - to develop $K_{p}$ values integrated at the irrigation zone and entire landscape level.

\section{Material and Methods}

\section{Experimental site and design}

This study was conducted at the Utah Botanical Center (UBC), Kaysville, UT (lat. $41^{\circ} 01^{\prime} 21^{\prime \prime} \mathrm{N}$, long. $\left.111^{\circ} 56^{\prime} \mathrm{W}\right)$. Annual precipitation averages $432 \mathrm{~mm}$ (Moller and Gillies, 2008), mostly as snow. The experimental site has a high mountain desert climate with temperature extremes ranging from $-30{ }^{\circ} \mathrm{C}$ in January to $41{ }^{\circ} \mathrm{C}$ in July. Average daily temperatures range from $-4^{\circ} \mathrm{C}$ in January to $24^{\circ} \mathrm{C}$ in July. Soil is a Kidman fine sandy loam (coarse-loamy, Mixed, Mesic Calcic Haploxeroll) (United States Department of Agriculture, 1968).
The experimental layout consisted of three different landscape treatments with three replicates (three treatments $\times$ three replicates) installed in nine large drainage lysimeter plots $\left(61.3 \mathrm{~m}^{3}, 9.14 \mathrm{~m}\right.$ long $\times 6.1 \mathrm{~m}$ wide $\times$ $1.1 \mathrm{~m}$ deep each). For each lysimeter plot, the surface was laser-leveled to prevent horizontal surface water flow, whereas the bottom was graded at a $3 \%$ slope along its length and then lined with a $4.5-\mathrm{mm}$ thick pond liner. A $10.16-\mathrm{cm}$ diameter perforated polyvinyl chloride drain pipe encased in a silt sleeve was installed in a 2- to $3-\mathrm{cm}$ diameter gravel bed at the low end to facilitate drainage to a collection well as shown in Figure 1, allowing monitoring of water quantity leaching through the soil profile of each lysimeter. Once lined and plumbed, subsoil and topsoil were returned to each plot and compacted to simulate original soil bulk densities of $\approx 1.6 \mathrm{~g} \cdot \mathrm{cm}^{-3}$.

Landscape treatments were assigned in a completely randomized block design (Fig. 1) and were three putative plant material water use classifications: mesic (conventional landscape species), xeric (native/adapted plant species of the IMW), and mixed (both conventional and IMW native species) replicated three times. Each treatment lysimeter plot was divided into three hydrozones: woody plants, turf, and perennials (Fig. 1). Turf zones were bordered by steel edging 4 $\mathrm{cm}$ into soil and $2 \mathrm{~cm}$ above soil to prevent root growth outside the turf area; this edging also prevented water from running off the turf hydrozone. Planting plans for landscapes were spatially identical, differing only in plant species used in the putative water use classification treatments (Table 1). Plants were purchased from local retail nurseries and installed using accepted horticultural practices in 2004. Irrigation systems, soil properties, mulches, and maintenance practices were the same for all plots. Bark mulch was applied to woody plant and perennial hydrozones to $\approx 0.1 \mathrm{~m}$ depth to prevent soil water evaporation. Woody plants and perennials were pruned in June 2009 and May 2010 to facilitate plant growth and to ensure plants in the same treatment were similar in size and pruned back to the plot edge at the beginning of each growing season. Fertilizer was applied to turf at a rate of $146.5 \mathrm{~kg} \mathrm{~N} / \mathrm{ha} /$ year divided into three applications in spring, midsummer, and late fall; trees, shrubs, and perennials were not fertilized during the study because fertilization to xeric plants may lead to mortality and no nutrient stress symptoms were observed for all the perennials and woody plants for the 5 years before the study. Mesic and mixed turf were mowed weekly in 2009 and biweekly in 2010, whereas xeric turf was mowed approximately once every 3 weeks in both years, mowing frequency changed as a result of labor availability. However, the species were maintained within recommended mowing height ranges throughout the study.

Three 2.54-cm solenoid valves were installed (Rain Bird DV Series; Rain Bird
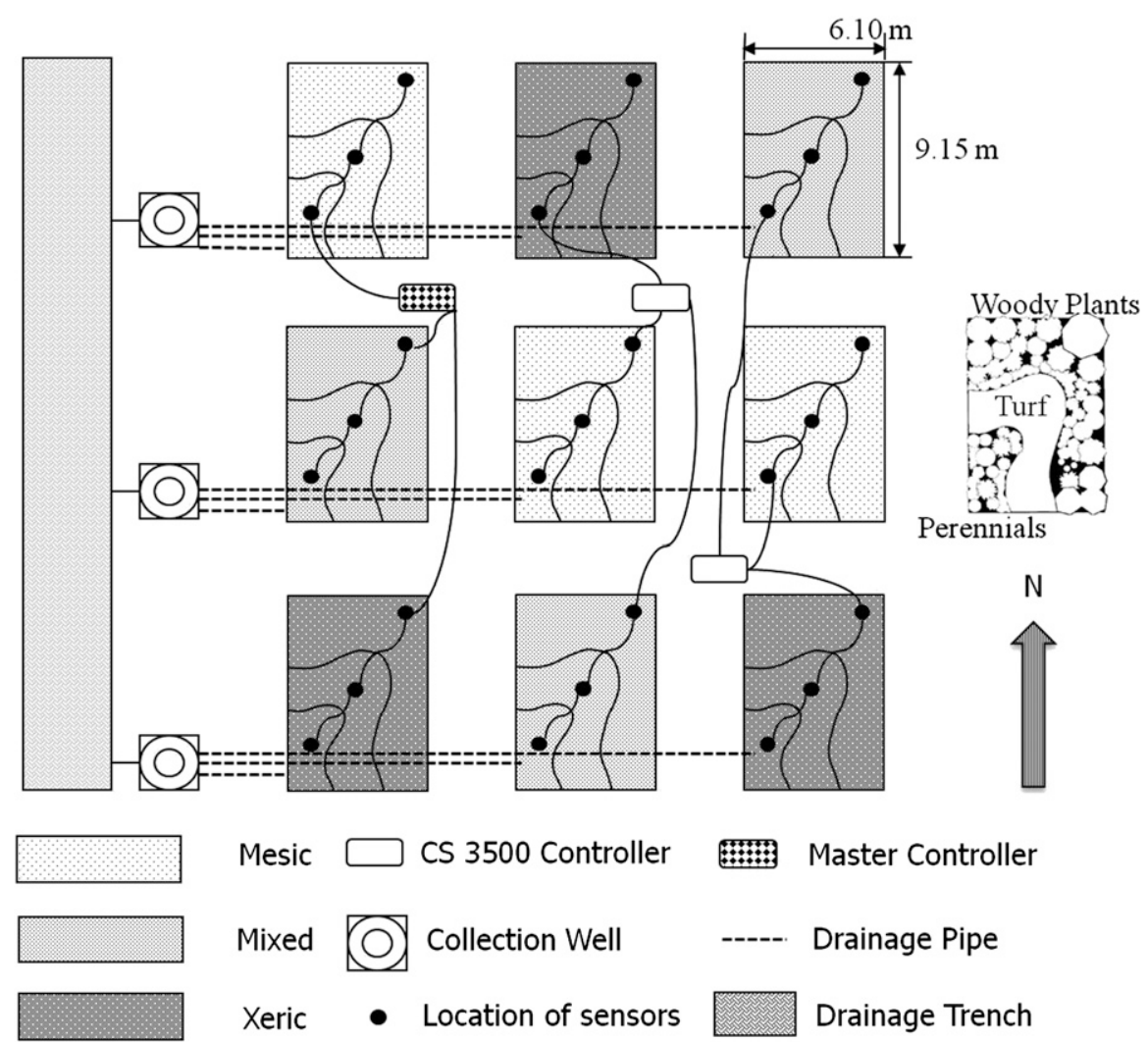

Fig. 1. Diagram of plots including size and conceptual design of each plot, landscape treatments, and location of sensors and controllers, collection wells, drainage pipes, and drainage trench. 
Table 1. Plant list for mesic, mixed, and xeric landscapes.

\begin{tabular}{|c|c|c|c|c|}
\hline & Plant type & Mesic & Mixed & Xeric \\
\hline \multirow[t]{7}{*}{ Woody } & Evergreen tree & Pinus heldrichi 'Leucodermis' & Pinus aristata & Pinus edulus \\
\hline & Broadleaf evergreen & Buxus microphylla koreana & Euonymus kiautschovicus & $\begin{array}{l}\text { Arctostaphylos coloradoensis } \\
\text { 'Panchito' }\end{array}$ \\
\hline & Evergreen shrub & Thuja occidentalis 'Little Giant' & Pinus mugo 'Pumilio' & Mahonia repens \\
\hline & Deciduous shrubs & Spiraea bumalda 'Anthony Water' & Syringa meyeri & Potentilla fruticosa \\
\hline & & Euonymus alatus 'Compactus' & Berberis thunbergii autropurpurea & Purshia tridentata \\
\hline & & Cornus sericea 'Kelseii' & Viburnum juddii & Chamaebatiaria millefolium \\
\hline & & Salix purpurea 'Nana' & Caragana arborescens 'Compacta' & Fallugia paradoxa \\
\hline \multirow[t]{8}{*}{ Perennial } & Herbaceous perennial & Paeonia lactiflora 'Nippon Beauty' & Penstemon digitalis & Penstemon strictus \\
\hline & & Hemerocallis hybrids & Sedum spectabile & Sphaeralcea grossulariaefolia \\
\hline & & Salvia $\times$ superba & Lavandula angustifolia & Artemesia ludoviciana 'Silver King' \\
\hline & & Phlox subulata 'Emerald Cushion Blue' & Oenothera missouriensis & Eriogonum corymbosum \\
\hline & & Chrysanthemum superbum & Rudbeckia occidentalis & Ratibida columnaris \\
\hline & & Aster novae-angliae 'Purple Dome' & Gaura lindheimeri 'Siskiyou Pink' & Geranium viscosissimum \\
\hline & Ground cover & Thymus pseudolanuginosus & Sedum spurium & Penstemon pinifolius \\
\hline & & Vinca minor & Delosperma floribundum & Antennaria microphylla \\
\hline \multirow[t]{3}{*}{ Turf } & Long grass & Miscanthus sinensis & Calamagrostis acutiflora & Elymus cinereus \\
\hline & Short grass & Helictotrichon sempervirens & Festuca ovina glauca & Festuca idahoensis \\
\hline & & Poa pratensis L. & Festuca arundinacea Schreb. & Buchloë dactyloides \\
\hline
\end{tabular}

Corporation, Azusa, CA) for each treatment lysimeter to distribute water according to woody, turf, and perennial hydrozones. Pop-up sprinklers (15.24 cm) (Rain Bird 1800 Series) with $1.83-\mathrm{m}$ variable arc nozzles (Rain Bird 6VAN) were installed in each turf hydrozone. Drip emitters (51 and $194 \mathrm{~L} \cdot \mathrm{h}^{-1}$ ) were installed for woody plant and perennial wildflower hydrozones in each treatment lysimeter, respectively. Emitters were distributed based on location of each plant (each plant was assigned one emitter), except for groundcovers and trees, which had two or three emitters depending on their size.

\section{Irrigation control}

In each hydrozone, four Acclima soil moisture sensors (Acclima Inc., Meridian, ID) were installed at $80,45,20$, and $5 \mathrm{~cm}$ depth. Three Acclima CS3500 irrigation controllers were installed and each controller was connected to 36 sensors (three plots $\times$ three hydrozones $\times$ four sensors) from one of mesic, mixed, and xeric treatments representing a replicated block (Fig. 1). Three lysimeter plots in one of the blocks (one each of mesic, mixed, and xeric landscapes) were chosen as master plots and connected to the master controller (Fig. 1) and the other two plots of each treatment were set as slaved plots under the same treatment master plot. The Acclima CS3500 master controller was then used to control irrigation for all lysimeter plots. In master lysimeter plots, sensors at $5 \mathrm{~cm}$ for three turf hydrozones and $20 \mathrm{~cm}$ for three each of woody plant and perennial hydrozones were used to control irrigation in three plant types by detecting volumetric water content that exceeded set water level thresholds. When volumetric soil moisture readings decreased below the set threshold, controlling sensors activated irrigation valves. Irrigation was stopped when soil water content readings of the controlling sensors reached field capacity $(28.8 \%)$ for all three plant types. Soil moisture sensor readings in woody and perennial hydrozones were affected by proximity to nearby emitters. To avoid variation caused by emitter locations, soil moisture sensor readings were monitored weekly and emitter locations were adjusted weekly as needed.

Average field capacity is generally described by $\theta$ at $-0.033 \mathrm{MPa}$ matric potential $\left(\theta_{\mathrm{FC}}\right)$ and average permanent wilting point is generally described by $\theta$ at $-1.5 \mathrm{MPa}$ matric potential $\left(\theta_{\mathrm{PWP}}\right)$. The difference between $\theta_{\mathrm{FC}}$ and $\theta_{\text {PWP }}$ is plant-available water (PAW) (Blonquist et al., 2006). Threshold water content $\left(\theta_{\text {Thresh }}\right)$ is the water content level to which soil is allowed to dry before the next irrigation event. Thus, $\theta_{\text {Thresh }}$ lies between $\theta_{\mathrm{FC}}$ and $\theta_{\mathrm{PWP}}$ and can be established through selection of a management allowed depletion (MAD) value (Cuenca, 1989). The MAD is the percentage of PAW that can be extracted from the plant root zone before irrigation is required and can be used to calculate $\theta_{\text {Thresh }}$ :

$$
\theta_{\text {Thresh }}=\theta_{\mathrm{FC}}-\operatorname{MAD}\left(\theta_{\mathrm{FC}}-\theta_{\mathrm{PWP}}\right)
$$

where all $\theta$ values are dimensionless values $\left[\mathrm{L}^{3} \cdot \mathrm{L}^{-3}\right]$ representing percentage of volume of water relative to total volume of soil considered. Cuenca (1989) reported MAD values of $33 \%$ for shallow rooted turf, $50 \%$ for medium-rooted perennials, and $67 \%$ for deep-rooted woody plants.

In this study, MAD values of $33 \%, 50 \%$, and $67 \%$ were used for turf, perennial, and woody plant hydrozones, respectively. Field capacity and $\theta_{\text {PWP }}$ were calculated with the van Genuchten water retention curve (van Genuchten, 1980). Threshold water content and field capacity for irrigation of each hydrozone were: woody plants $(14.2 \%$ and $28.8 \%$ ); turf ( $22.4 \%$ and $28.8 \%$ ); and perennials (18.4\% and $28.8 \%$ ). To avoid overlapping irrigations and to make sure water pressure was the same for each hydrozone, the Acclima CS 3500 controller's built-in function "max zones watering simultaneously" was set to only one zone, and daily allowed irrigation time period was set between $2000 \mathrm{HR}$ to $0800 \mathrm{HR}$ to reduce daytime evaporation. Although woody plant, turf, and perennial hydrozones were watered separately, each replicate was irrigated in the same manner and sequentially to achieve the same volume of water application. For example,
Poa pratensis L. in each mesic landscape was watered sequentially and received the same total volume of water. Irrigation duration for each slave hydrozone could be adjusted as percent of master hydrozone to adjust the difference in irrigation volume caused by sprinklers or emitters.

\section{Data collection}

Soil water content. In each hydrozone, four Acclima soil moisture sensors at depths of $80,45,20$, and $5 \mathrm{~cm}$ measured volumetric soil water content data representing soil layers between 100 to $60 \mathrm{~cm}, 60$ to $30 \mathrm{~cm}$, 30 to $10 \mathrm{~cm}$, and 10 to $0 \mathrm{~cm}$ every hour. The three Acclima CS3500 irrigation controllers had data logger capabilities and were used to log volumetric soil water content data hourly, and timing and duration of irrigation for each hydrozone of nine lysimeter plots were recorded by the master controller.

Leachate. Leachate from each landscape drained to collection wells adjacent to plots (Fig. 1) and was quantified using dipper trays connected to a CR1000 data logger (Campbell Scientific, Logan, UT). Nine manual counters were connected to dripper trays as a back-up to the data logger. Volume of each dip for each dipper tray was calibrated before installation, and dipping times were recorded every $10 \mathrm{~min}$ and logged weekly and manual counter data were collected weekly. Leachate volume was determined by the product of dipping volume and dipping times.

Irrigation data. A DLJ $1.905-\mathrm{cm}$ flow meter (Daniel L. Jerman Co., Hackensack, NJ) connected to a CR1000 data logger was installed in each plot and every $3.785 \mathrm{~L}$ of water applied to plots was recorded. Acclima CS3500 irrigation controllers recorded duration time of irrigation for each hydrozone, and the combination of irrigation volume and irrigation duration was used to determine amount of irrigation water applied to each hydrozone. If two zones in one lysimeter were irrigated one after another, duration was used to separate volume data.

Canopy cover estimation. In 2009, length and width of each plant in woody plant and 
perennial hydrozones were measured in midJuly and mid-September, and canopy cover of each plant type hydrozone was determined:

Canopy cover $=\sum$ width $*$ length $/$ area.

In 2010, a point-line intercept method (Salo et al., 2008) was used to estimate canopy cover monthly from May to October. With this method, canopy cover was measured along a linear transect line and was based on the number of "hits" on a target plant out of the total number of points measured along that line. In each plot, spacing between lines was $0.61 \mathrm{~m}$ and between points was $0.30 \mathrm{~m}$.

Turf root distribution. Measurements of effective turfgrass root length distribution were taken in May 2010. Soil samples from each turfgrass area were collected at depths of 0 to $10 \mathrm{~cm}, 10$ to $20 \mathrm{~cm}, 20$ to $30 \mathrm{~cm}, 30$ to $40 \mathrm{~cm}, 40$ to $60 \mathrm{~cm}$, and 60 to $80 \mathrm{~cm}$ using a soil auger, and soil was washed from roots in the laboratory. Root length density was measured by a modified line intersect method (Tennant, 1975). Roots were cut into $1-\mathrm{cm}$ lengths and randomly placed into a transparent dish, which was divided into $1 \times 1-\mathrm{cm}$ squares. Instances of intersections of roots on both vertical and horizontal lines were counted.

Root length $(\mathrm{R})=$ number of intercept

$(\mathrm{N}) *$ length conversion factor.

where conversion factor for $1-\mathrm{cm}$ grid squares is 0.7857 .

Root length density = root length/soil volume

After root length was measured, root samples were dried in an oven at $80{ }^{\circ} \mathrm{C}$ until a constant weight was reached, and dry weights of root samples were measured.

Weather data. In 2009, precipitation data were obtained from the UBC weather station located $200 \mathrm{~m}$ from research plots. Reference ET data (UN-FAO 56) (Allen et al., 2005b) was obtained from the Farmington, UT, weather station, located 2 miles from research plots as a result of a malfunction of the UBC weather station. In 2010, a TR-525i tipping bucket rain gauge (Campbell Scientific) was installed next to plots to collect precipitation data and the $\mathrm{ET}_{\mathrm{o}}$ data set was obtained from the UBC weather station.

\section{Data analysis}

Evapotranspiration calculation with water balance equation. Although it was not possible to separate drainage for each hydrozone in each lysimeter plot, drainage could be assigned to each hydrozone based on area and reading of soil moisture sensors at the 80$\mathrm{cm}$ depth in each hydrozone. For example, in spring, when drainage was greatest and caused by precipitation, it was assigned to each hydrozone based on area percentage of each hydrozone. In summer, overirrigation rarely happened as a result of closely controlled irrigation within water thresholds by the smart irrigation controller, and precipitation was negligible, so there was almost no leaching from the plots. If leaching did occur during summer months, and there was no precipitation, leachate was assigned to the turf hydrozone because turf was irrigated most frequently and had the greatest deep-soil water content. If the situation was unclear, readings of soil moisture sensors at $80 \mathrm{~cm}$ in each hydrozone were the determining factor in assigning the source of drainage. In addition to drainage data, irrigation data were available for each hydrozone, and water depth in the soil profile of each hydrozone was obtained by daily averaging of hourly soil moisture data:

$$
\begin{aligned}
& \text { Soil profile water depth }(\mathrm{mm})=\theta_{80} \times 400 \\
& \quad+\theta_{45} \times 300+\theta_{20} \times 200+\theta_{5} \\
& \quad \times 100(\mathrm{~mm})
\end{aligned}
$$

As a result, monthly $\mathrm{ET}_{\mathrm{a}}$ for each hydrozone during the growing season was calculated by a water balance equation:

Monthly hydrozone $\mathrm{ET}_{\mathrm{a}}=\Delta \mathrm{W}+$ Precipitation

$$
+ \text { Irrigation }- \text { Leachate }- \text { Runoff }
$$

where

$\Delta \mathrm{W}$ (water absorbed by plants $)=$ Initial Water

Depth - Final Water Depth

There was no runoff from the plots because each plot was lined to prevent water movement outside of the plot; thus, runoff was set to zero.

Plant factors. $\mathrm{K}_{\mathrm{p}}$ was calculated as: Monthly $\mathrm{K}_{\mathrm{p}}=$ Monthly ET $_{\mathrm{a}} /$ Monthly ET $_{\mathrm{o}}$

Based on calculated monthly $\mathrm{ET}_{\mathrm{a}}$ (Eq. 7), seasonal ET for the plant growing season from May to October was summed, and the sum of monthly $\mathrm{ET}_{\mathrm{o}}$ from May to October was denoted as seasonal $\mathrm{ET}_{\mathrm{o}}$ :

Seasonal $\mathrm{K}_{\mathrm{p}}=$ Seasonal $\mathrm{ET}_{\mathrm{a}} /$ Seasonal $\mathrm{ET}_{\mathrm{o}}$

Landscape coefficient. Because landscapes are comprised of woody plants, turf, and perennial hydrozones, each group of plants has different $\mathrm{K}_{\mathrm{p}}$ values, and overall water use of each landscape depends on both $K_{p}$ and percent area of each hydrozone. Area of each hydrozone was incorporated, thus obtaining adjusted $\mathrm{K}_{\mathrm{p}}$ for woody plants, turf, and perennials:

$$
\text { Adjusted } \mathrm{K}_{\mathrm{p}}=\mathrm{K}_{\mathrm{p}} \times \% \text { area }
$$

and $K_{1}$ of the entire landscape is the sum of adjusted $\mathrm{K}_{\mathrm{p}}$ for each hydrozone:

$$
\begin{aligned}
& \mathrm{K}_{\mathrm{l}}=\mathrm{K}_{\mathrm{p}}{ }^{\prime} \text { woody } \times \% \text { area }+\mathrm{K}_{\mathrm{p}}{ }^{\prime} \text { turf } \times \% \text { area } \\
& +\mathrm{K}_{\mathrm{p}}{ }^{\prime} \text { perennial } \times \% \text { area }
\end{aligned}
$$

Statistical analysis. To assess plant coverage on water use, $\mathrm{K}_{\mathrm{p}}$ was regressed on percent canopy cover for each plant type and water use categorization over both years (Table Curve 2-D, Version 5.01). This study was arranged in a completely randomized block design and canopy cover, adjusted $\mathrm{K}_{\mathrm{p}}$ and $\mathrm{K}_{1}$ data were analyzed using PROC GLM
(Version 9.1; SAS Inc., Raleigh, NC). When differences were significant, least-square means tests were used to separate differences among means $(P=0.05)$.

\section{Results and Discussion}

Weather conditions, soil water depletion, and irrigation timing for each hydrozone. In both years of the study, spring periods (April to June) were relatively cool and wet (Fig. 2). In 2009, the greatest seasonal precipitation occurred in April with cool wet conditions extending into June, resulting in significant soil water content peaks for all landscape treatments and irrigation zones in April (Fig. 3). In 2010 , rainfall was generally continuous from April to June; greatest precipitation occurred in May, also resulting in soil water content peaks during that period (Figs. 2 and $3)$. Compared with historical ET and precipitation, in 2009, May had similar $\mathrm{ET}_{0}$ to historical $\mathrm{ET}_{\mathrm{o}}$ with just $56 \%$ of historical precipitation, whereas June had $90 \%$ of historical $\mathrm{ET}_{\mathrm{o}}$ and $199 \%$ of historical precipitation. In 2010, May was wetter than usual with only $73 \%$ of historical $\mathrm{ET}_{\mathrm{o}}$ and $117 \%$ of historical precipitation, whereas June had $91 \%$ of historical $\mathrm{ET}_{\mathrm{o}}$ and $88 \%$ of historical precipitation. As air temperature and $\mathrm{ET}_{\mathrm{o}}$ increased, and rainfall decreased in July to August both years (Fig. 2), plants depleted soil water storage. Woody plants resulted in rapid decreases, whereas perennials resulted in slow decreases in soil water content in deep soil layers in each hydrozone in June and July of both years (Fig. 3).

In general, soil water content at $5 \mathrm{~cm}$ depth changed significantly after each irrigation application in each treatment, whereas soil water content at $20 \mathrm{~cm}$ was less responsive to irrigation input compared with soil water content at $5 \mathrm{~cm}$ (Fig. 3). Irrigation water rarely reached deep soil layers $(45 \mathrm{~cm}$ and $80 \mathrm{~cm}$ ) because depth of application was regulated by shallow soil sensors for all plant types.

Overall, woody plant water consumption came primarily from water stored in soil in early summer, and irrigation only began to supply water when soil moisture sensors at 20 $\mathrm{cm}$ detected lower water content threshold later in the growing season. In 2009, $62 \mathrm{~mm}$ of June rainfall forestalled irrigation onset for mesic, mixed, and xeric woody treatments until July; in 2010, $27 \mathrm{~mm}$ of June rainfall initiated earlier soil water depletion and irrigation onset (Table 2; Fig. 3). In both years, xeric woody plants depleted soil water at $20 \mathrm{~cm}$ more rapidly and initiated irrigation earlier than mesic and mixed treatments (Table 2). Once seasonal hot and dry conditions began both years, woody plants rapidly depleted deep soil water within the entire soil profile to a greater degree than turfgrasses or perennials. Unexpectedly, xeric woody plants had greater irrigation frequency and greater deep soil water content than mesic and mixed woody plants in this study, suggesting more opportunistic root systems acclimated to an unlimited shallow water 


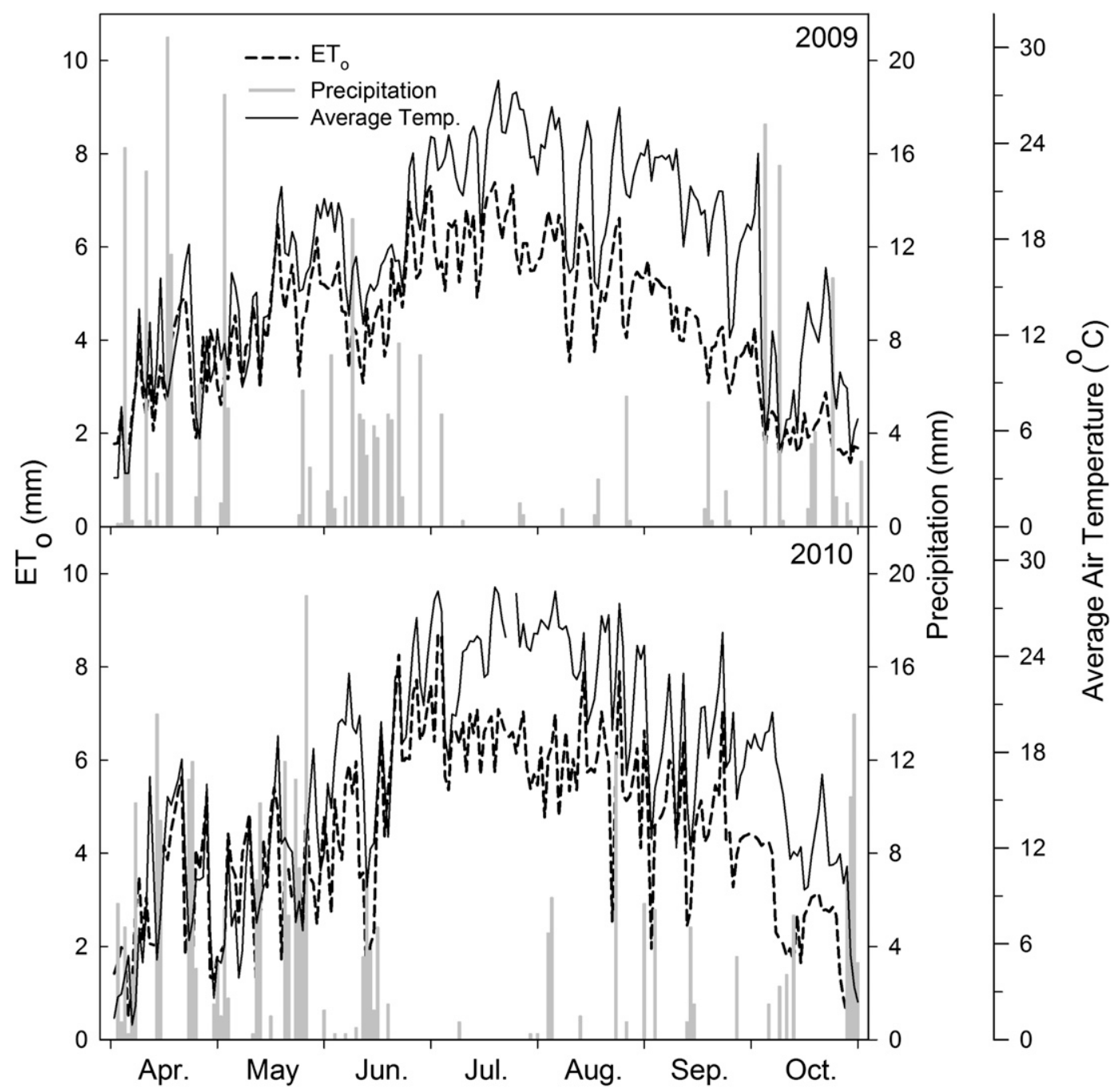

Fig. 2. Reference evapotranspiration ( $\left(\mathrm{ET}_{\mathrm{o}}\right.$ ), precipitation, and average temperature from April to October in 2009 and 2010 (Kaysville, UT).

supply. In contrast, mixed woody plants in 2010 did not deplete water to the point of triggering irrigation until early August (Table 2).

Perennials exhibited water depletion trends similar to woody plants, initiating irrigation earlier in 2010 than 2009. Perennials differed from woody plants in using less water deeper in the soil profile (Table 2), because water contents at $80 \mathrm{~cm}$ were much greater than for woody plants (Fig. 3). This suggests woody plants were deeper rooted with greater water uptake ability deeper in the soil. In both 2009 and 2010, mixed perennial plants had greater irrigation frequency than both xeric and mesic perennials, indicating shallow rooting for this particular configuration of plants compared with species used in the xeric and mesic treatments. Shallower root systems could account for greater irrigation of mixed perennials compared with mesic and xeric perennials. Mesic perennials had similar irrigation depths to mixed perennials in 2009 but much less irrigation frequency and irrigation depth in 2010 . Unexpectedly low irrigation frequency and depth in mesic perennials in 2010 may have resulted from malfunction of the controlling soil moisture sensor in the master mesic perennial hydrozone in 2010.

Turf irrigation began earlier than other plant types but was similar in starting later in 2009, at the beginning of May, compared with end of Apr. 2010 (Table 2; Fig. 3). Because the irrigation-controlling soil moisture sensor was located at $5 \mathrm{~cm}$ and the threshold for turf was higher than that of woody plants and perennials, meaning less allowable water that could be depleted, this triggered greater watering frequency. Frequent irrigation promoted shallow rooting in upper $10 \mathrm{~cm}$ of soil $(76 \%, 76 \%$, and $24 \%$ for mesic, mixed, and xeric, respectively, according to root length density; $88 \%, 88 \%$, and $53 \%$ for mesic, mixed, and xeric turf species, respectively, according to root dry weight). As a result, turf relied more on shallow soil water and had little encouragement to deplete deep soil water under wellwatered conditions of this study. However, deep roots at $80 \mathrm{~cm}$ were observed but were rather sparse in all species $(2 \%, 2 \%$, and $15 \%$ for mesic, mixed, and xeric, respectively, according to root length density; $1 \%, 1 \%$, and $11 \%$ for mesic, mixed, and xeric turf species, respectively, according to dry weight). Only mesic kentucky bluegrass slowly depleted deep soil water over the growing season in both years to less than $20 \%$. For mixed tall fescue and xeric buffalograss, considered deep-rooted and drought-tolerant turf species (Carrow, 1996; Stewart et al., 2004), deep soil water content was mid-20\% throughout both growing seasons (Fig. 3), even when a mesic turf irrigation valve malfunctioned in 2009 for a brief period.

This pattern of shallow rooting under frequent irrigation suggests mixed tall fescue and xeric buffalograss may have opportunistic root systems that preferentially use shallow water under frequent, shallow irrigation, relying on deep roots to exploit deep soil water when surface water supplies are depleted. Mesic kentucky bluegrass appears to have a resourceful root strategy, depleting water throughout the soil profile through dense shallow roots and sparse deep roots (Stewart et al., 2004), resulting in lesser deep soil water content at the end of the growing season compared with the other turf species. However, under drought conditions, mixed tall fescue and xeric buffalograss turfgrasses 


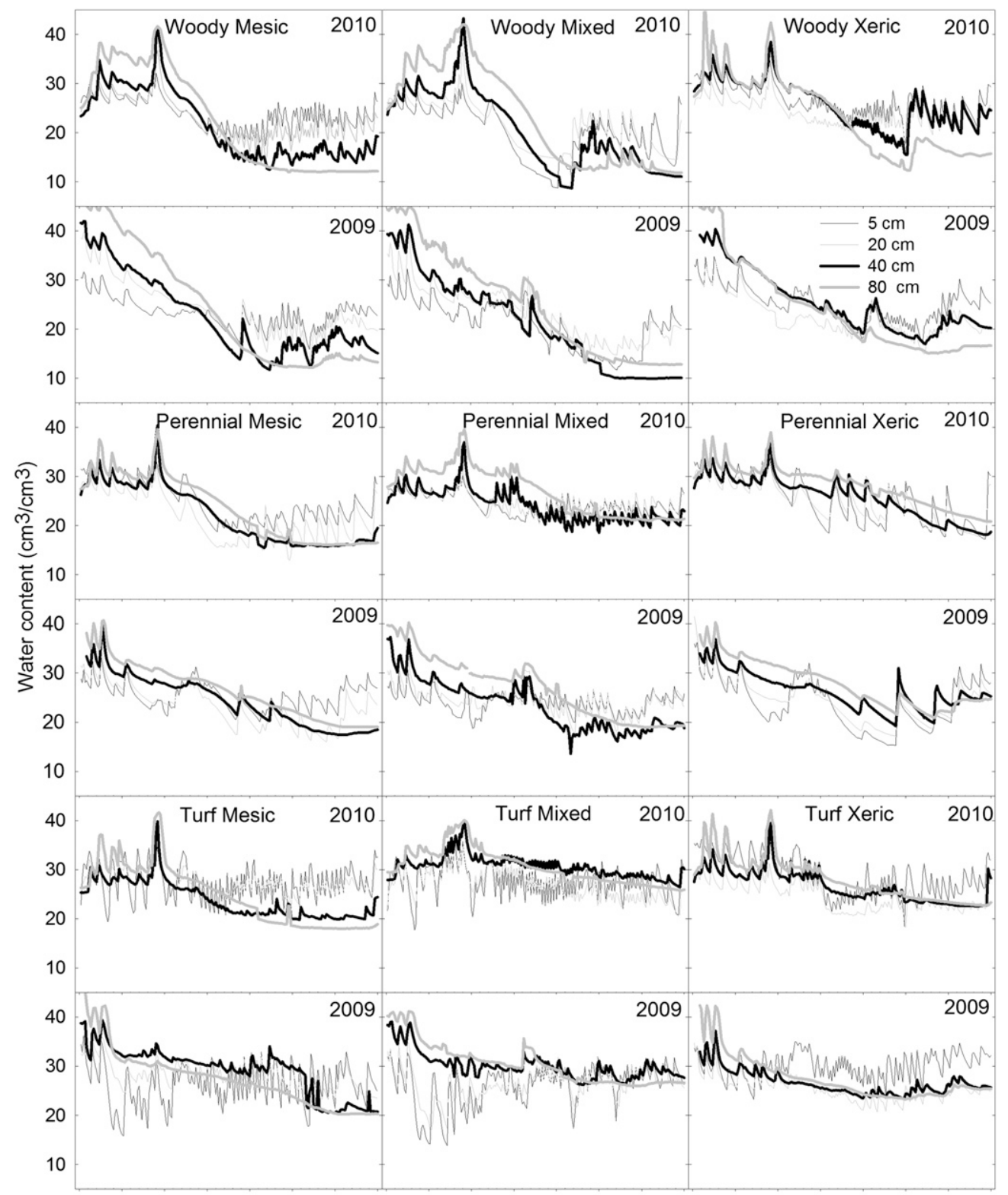

Apr. May Jun. Jul. Aug. Sep. Oct. Apr. May Jun. Jul. Aug. Sep. Oct. Apr. May Jun. Jul. Aug. Sep. Oct.

Fig. 3. Water depletion of soils $(\mathrm{n}=3)$ at $5,20,45$, and $80 \mathrm{~cm}$ under woody plant, herbaceous perennial, and turf plant types in mesic, mixed, and xeric landscapes from April to October in 2009 and 2010 (Kaysville, UT).

may deplete deeper soil water after shallow soil moisture is depleted (Carrow, 1996), suggesting a small number of roots deep in soil may contribute substantially to a plant's ability to avoid drought (Ervin and Koski, 1998).

Monthly evapotranspiration and plant factor: woody plants and perennials. Monthly $\mathrm{ET}_{\mathrm{a}}$ of each hydrozone was determined based on developed water balances (Fig. 4). Under well-watered conditions, ET of woody plants and perennials closely followed $\mathrm{ET}_{\mathrm{o}}$ during the growing season in both years of study (May to October). Previous research has found water use rates of many woody plant species may not closely follow $\mathrm{ET}_{\mathrm{o}}$ because they are drought-tolerant and can maintain acceptable aesthetic appearance under soil water deficits (Kjelgren et al., 2000) and, in less humid climates, are susceptible to high vapor deficitinduced stomatal closure and reduced transpiration (Kjelgren et al., 2005). Under well-watered conditions of this study, water use rates of integrated woody plants did closely follow $\mathrm{ET}_{\mathrm{o}}$.

Actual ET of woody plants was least in May, increased in June, reached a peak in July or August, depending on treatment, and decreased in September and October (Fig. 4). Generally, mixed woody plants had lesser $\mathrm{ET}_{\mathrm{a}}$ than mesic and xeric woody plants, whereas mesic woody plants had greatest $\mathrm{ET}_{\mathrm{a}}$ among the three treatments. This finding is likely the result of different woody plant canopy covers (Table 2). Mesic woody plants had the greatest canopy cover in both 2009 and 2010, whereas mixed woody plants had the least canopy cover in both years (Table 2).
Mesic, mixed, and xeric perennials had lesser $\mathrm{ET}_{\mathrm{a}}$ than $\mathrm{ET}_{\mathrm{o}}$ and $\mathrm{ET}_{\mathrm{a}}$ of the other two plant types during the study (Fig. 4). Actual ET of mesic, mixed, and xeric perennials, however, were very similar in May, June, September, and October of 2009. Additionally, there were no differences in canopy cover observed in 2009 among mesic, mixed, and xeric perennials (Fig. 4; Table 2). In $2010, \mathrm{ET}_{\mathrm{a}}$ of the three perennial treatments generally followed the trend of $\mathrm{ET}_{\mathrm{o}}$ (Fig. 4). Xeric perennials had the least $\mathrm{ET}_{\mathrm{a}}$ in June and lesser $\mathrm{ET}_{\mathrm{a}}$ than mixed perennials in July. Xeric perennials also had less canopy cover than mesic and mixed perennials (Fig. 4; Table 2). Mesic perennials had greater canopy cover than xeric perennials in 2010 (Table 2). However, $\mathrm{ET}_{\mathrm{a}}$ of the two treatments was similar in July 2010 (Fig. 4). This 
Table 2. Irrigation frequency, start date, duration days, depth, soil water use, total water use, ratio of irrigation and soil water use, canopy cover, and seasonal plant factors $\left(\mathrm{K}_{\mathrm{p}}\right)$ for woody, turf, and perennial hydrozones in mesic, mixed, and xeric landscapes in 2009 and 2010 (Kaysville, UT). ${ }^{\mathrm{z}}$

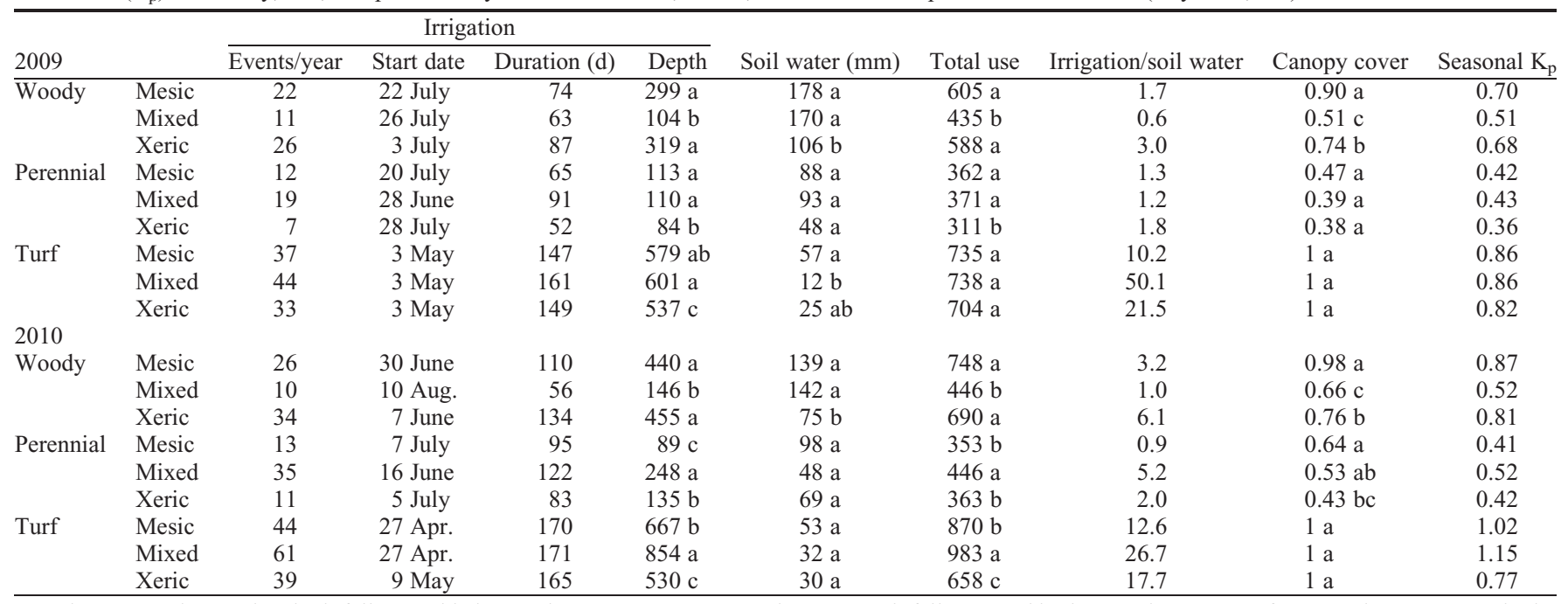

${ }^{\mathrm{z}}$ Leachate was subtracted and rainfall was added to total water use. $184 \mathrm{~mm}$ and $215 \mathrm{~mm}$ rainfall occurred in the growing season of 2009 and 2010, respectively. Data within a column of each year (2009 and 2010) and each plant type (woody, perennial, and turf) not followed by same letter are different at $P \leq 0.05$.

finding is likely the result of an unintended water deficit that occurred in July 2010 when a controlling moisture sensor malfunctioned in the mesic perennial hydrozone.

Plant factors combined over a range of woody plants in this study ranged from 0.2 to 1.0 and varied from month to month (Fig. 5). Generally, woody plants had lesser $\mathrm{K}_{\mathrm{p}}$ values at the beginning of the growing season and reached greater $K_{p}$ values during the late growing season. This finding was likely the result of increasing canopy cover and suggests a close relationship between canopy cover and water use in the landscapes studied. For perennials, $K_{p}$ values were lower than woody plants ( 0.4 vs. 0.7 on average) and likely resulted from less canopy cover in perennial hydrozones (Fig. 5; Table 2). Plant factors for non-turf landscape plants have not been widely examined because of great species diversity and difficulty in quantifying $\mathrm{K}_{\mathrm{p}}$ values. For many woody species, stomatal sensitivity to high vapor pressure deficits and close coupling to atmospheric conditions result in a declining rate of water loss at high $\mathrm{ET}_{\mathrm{o}}$ rates (Buwalda and Lenz, 1995). Such nonlinearity suggests a wide range of $\mathrm{K}_{\mathrm{p}}$ for woody plants, depending on $\mathrm{ET}_{\mathrm{o}}$ conditions. For example, coefficients ranging from 0.2 to 0.8 of $\mathrm{ET}_{\mathrm{o}}$ have been suggested for woody plants (Buwalda and Lenz, 1995), and coefficients from 0.2 to 1 have been observed in a range of broadleaf tree species (Montague et al., 2004).

The importance of canopy cover is illustrated in Figure 6. A linear relationship between $\mathrm{K}_{\mathrm{p}}$ and percent canopy cover $\left(r^{2}=\right.$ 0.88 ) of woody plants and perennials was found when both years of study were combined, indicating canopy cover was the controlling factor for water use of non-turf plants under well-watered conditions. Turf $\mathrm{K}_{\mathrm{p}}$ values are included as reference points (Fig. 6).

Monthly evapotranspiration and plant factor: turf. Actual monthly evapotranspiration

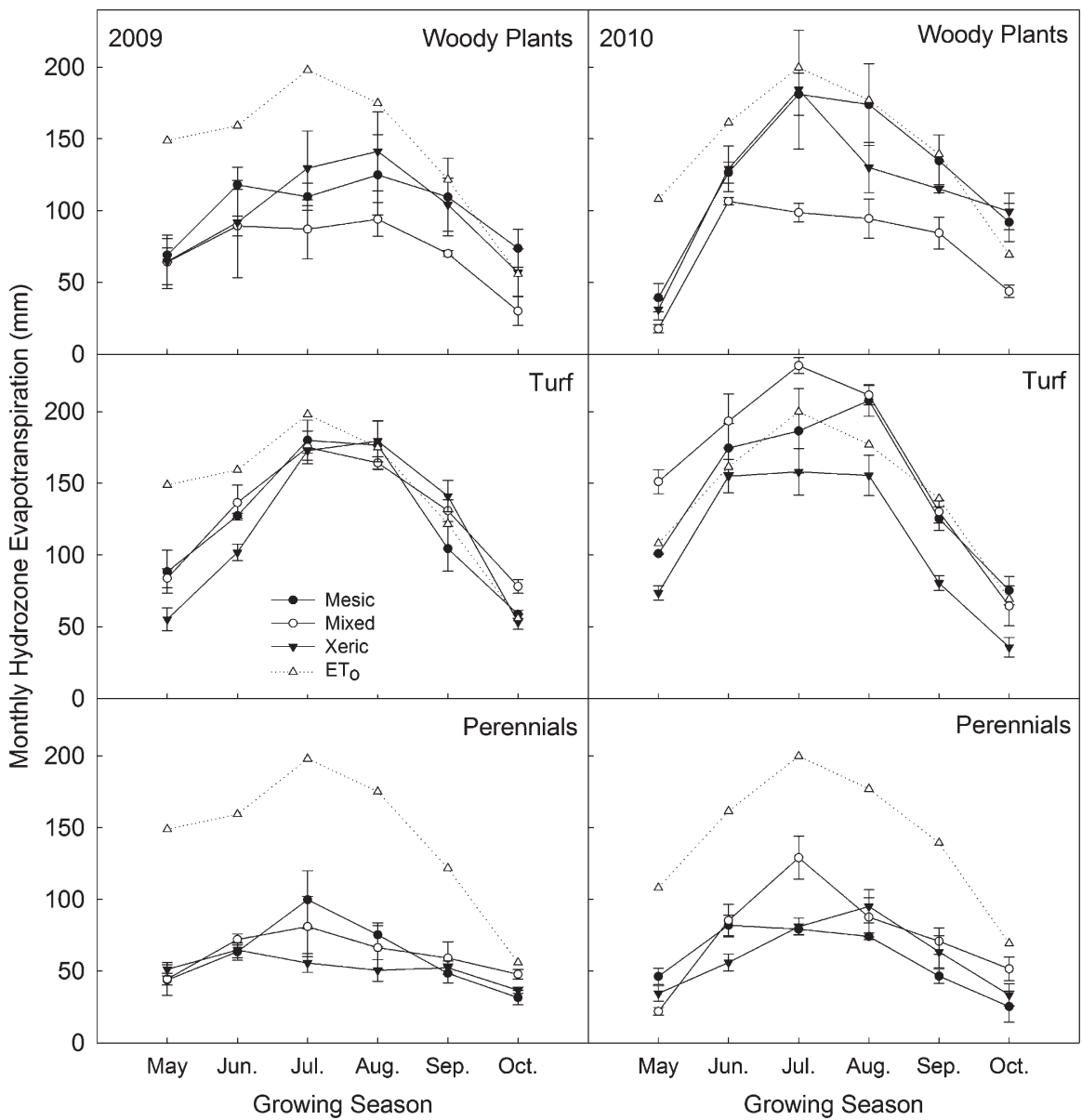

Fig. 4. Monthly evapotranspiration $\left(\mathrm{ET}_{\mathrm{a}}\right)($ mean $\pm \mathrm{SE}, \mathrm{n}=3)$ of woody plants, turf, and perennials in mesic, mixed, and xeric landscapes constructed in large drainage lysimeters from May to October in 2009 and 2010 (Kaysville, UT).

of all turf species was close to $\mathrm{ET}_{\mathrm{o}}$ and followed the same trend as $\mathrm{ET}_{\mathrm{o}}$ (Fig. 4), although month-to-month variation was high, as has been reported for turfgrass (Carrow,
1995). Mixed tall fescue had greater $\mathrm{ET}_{\mathrm{a}}$ than $\mathrm{ET}_{\mathrm{o}}$ in October of 2009 and during the first 4 months of the growing season in 2010 . We suspect misalignment between the soil 


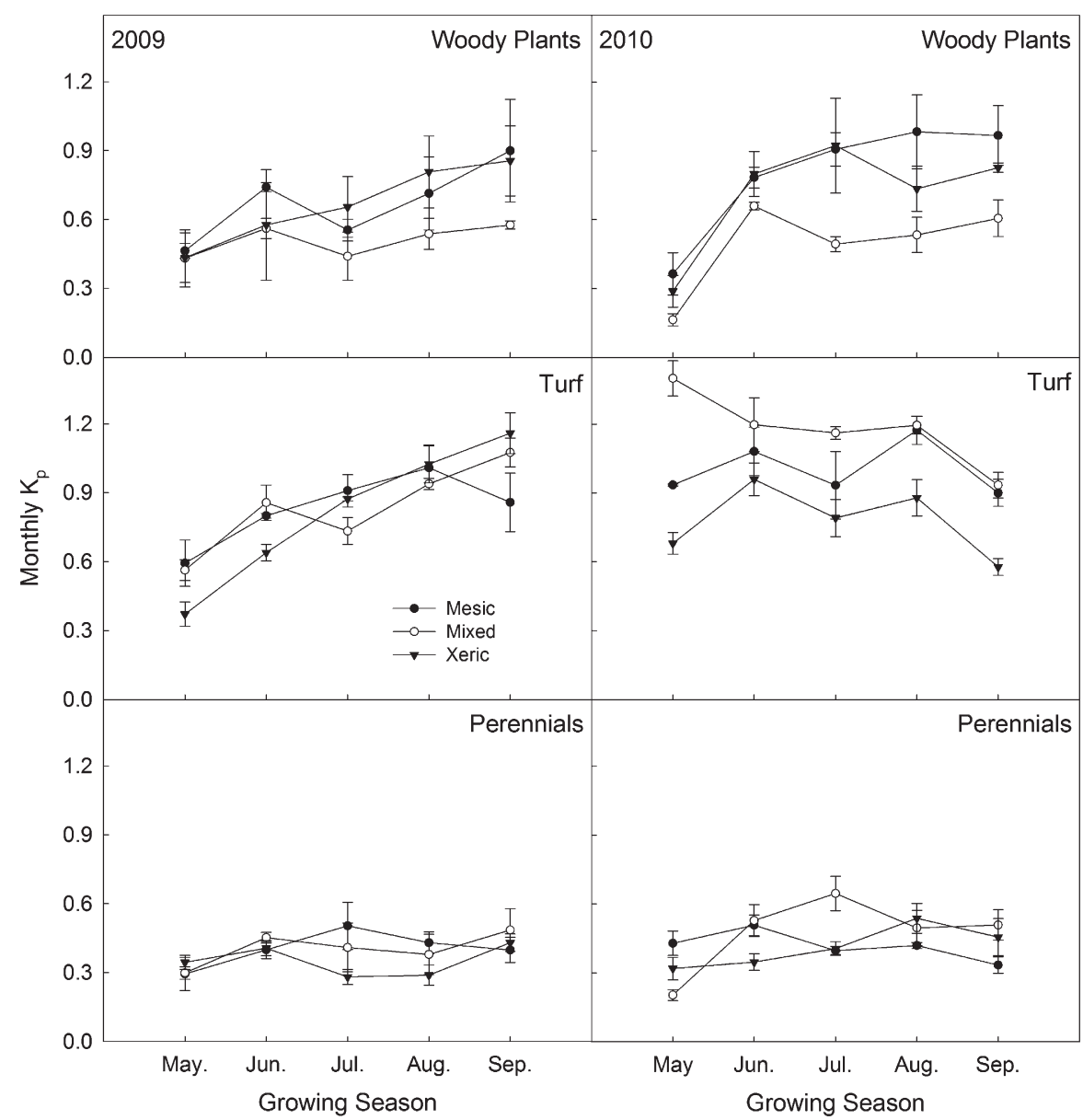

Fig. 5. Plant factors $\left(\mathrm{K}_{\mathrm{p}}\right.$; mean $\pm \mathrm{SE}, \mathrm{n}=3$ ) of woody plants, turf, and perennials for mesic, mixed, and xeric landscapes constructed in large lysimeters over the growing season from May to September in 2009 and 2010 (Kaysville, UT).

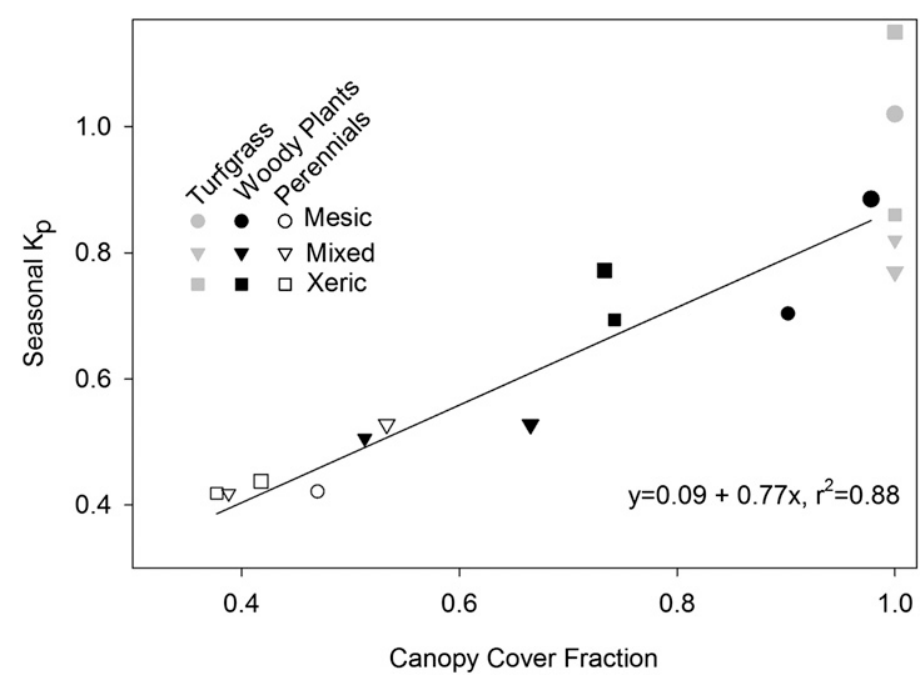

Fig. 6. Relationship between seasonal plant factors $\left[\mathrm{K}_{\mathrm{p}}\right.$; plant water use as a fraction of reference evapotranspiration $\left(\mathrm{ET}_{\mathrm{o}}\right)$ ] and canopy cover for woody plants and perennials in mesic, mixed, and xeric landscapes in 2009 and 2010 (Kaysville, UT). Large points show data in 2009 and small points show data in 2010. Turfgrass $\mathrm{K}_{\mathrm{p}}$ values are included as reference points. Mesic and mixed turf $\mathrm{K}_{\mathrm{p}}$ values overlapped in 2009.

water sensor and irrigation may have triggered greater irrigation frequency than was warranted by actual turf water use. Mesic kentucky bluegrass $\mathrm{ET}_{\mathrm{a}}$ was nearly same as
$\mathrm{ET}_{\mathrm{o}}$ during every month of the 2 years, except in August of 2010. Xeric buffalograss had lesser $\mathrm{ET}_{\mathrm{a}}$ than $\mathrm{ET}_{\mathrm{o}}$ in the early season of both years, possibly as a result of cooler conditions delaying full development of this $\mathrm{C}_{4}$ species.

A variety of factors affect turf $\mathrm{K}_{\mathrm{p}}$ values: turf type $\left(\mathrm{C}_{3}\right.$ cool vs. $\mathrm{C}_{4}$ warm-season grasses), turf quality, stage of development, and, to a lesser degree, turf height (Brown and Kopec, 2000). As a general rule, $C_{3}$ water use is greater than $\mathrm{C}_{4}$, and in this study, xeric warm-season species used $8 \%$ and $11 \%$ less irrigation than mesic and mixed cool-season species in 2009 and $21 \%$ and $38 \%$ less irrigation than mesic and mixed cool-season species in 2010. Overall $\mathrm{K}_{\mathrm{p}}$ values for mesic and mixed cool-season species were greater than xeric warm-season species in early 2009 and all of 2010 (Fig. 5). However, in some cases, warm-season grass water use may approach cool-season grass water use rates under well-watered conditions (Brown et al., 2001; Devitt et al., 1992; Jia et al., 2009). In this study, similar $\mathrm{ET}_{\mathrm{a}}$ and $\mathrm{K}_{\mathrm{p}}$ of mesic, mixed, and xeric grasses were observed in July and August of 2009 (Figs. 4 and 5). Of the three plant types, turf $\mathrm{K}_{\mathrm{p}}$ has been studied most, and $\mathrm{K}_{\mathrm{p}}$ values observed in this study were comparable to previous research. For example, values of $\mathrm{K}_{\mathrm{p}}$ reported for cool-season turfgrasses range from 0.72 to 1.23 of $\mathrm{ET}_{\mathrm{o}}$ (Aronson et al., 1987) compared with 0.6 to 1.2 in our research, whereas those for warm-season turfgrasses range from 0.67 to 0.84 compared with from 0.5 to 1.0 in our research (Carrow, 1995).

Plant factors integrated by zone and landscape. Adjusted $\mathrm{K}_{\mathrm{p}}$ for each hydrozone was calculated based on landscaped area covered by plant types studied as a percent of total area (Table 3). The percent of total landscape area covered by woody plants, turfgrass, and perennials in this study totaled $43 \%, 35 \%$, and $22 \%$, respectively. Mesic and xeric woody plants had similar adjusted $K_{p}$ values that were greater than adjusted $\mathrm{K}_{\mathrm{p}}$ for mixed woody plants (because of greater $K_{p}$ ). However, perennial adjusted $K_{p}$ values were very similar for all landscape treatments in both 2009 and 2010 because their water use was similar and lesser than other plant types as a result of less canopy cover and lower percent area. For turfgrasses, xeric buffalograss had lesser adjusted $\mathrm{K}_{\mathrm{p}}$ than mesic kentucky bluegrass and mixed tall fescue species, again because of lower water use. Turf-adjusted $\mathrm{K}_{\mathrm{p}}$ values were greater than that of woody plants and perennials as a result of high turf $K_{p}$ and relatively large turf canopy areas in landscapes. Although adjusted $K_{p}$ values for each hydrozone cannot be used as a guideline for irrigation control in landscapes, they do reflect differences in canopy cover and plant types useful for assessing water conservation of an entire landscape. In the case of this study, plant types refer to turf vs. non-turf plants with potentially variable canopy cover rather than woody, perennial, or groundcover types previously suggested (Bos et al., 2008; Eching and Snyder, 2005; EPA WaterSense, 2009).

Overall, $\mathrm{K}_{1}$ of the landscapes ranged from 0.6 to 0.8 under well-watered conditions of this study (Table 3). Mesic landscape had the highest $\mathrm{K}_{1}$ for both years of study. Mixed landscape had lesser $K_{1}$ in 2009, whereas 
Table 3. Adjusted plant factors $\left(\mathrm{K}_{\mathrm{p}}\right)$ based on percent of area for woody plant, turf, and perennial hydrozones and total landscape factor $\left(\mathrm{K}_{1}\right)$ of landscapes in mesic, mixed, and xeric landscapes in 2009 and 2010 (Kaysville, UT).

\begin{tabular}{|c|c|c|c|c|}
\hline \multirow{3}{*}{$\begin{array}{l}\text { Percent } \\
\text { area }\end{array}$} & \multicolumn{3}{|c|}{ Adjusted $\mathrm{K}_{\mathrm{p}}$} & \multirow{3}{*}{$\begin{array}{c}\text { Total } \mathrm{K}_{1} \\
100 \%\end{array}$} \\
\hline & Woody & Turf & Perennial & \\
\hline & $43 \%$ & $35 \%$ & $22 \%$ & \\
\hline \multicolumn{5}{|l|}{2009} \\
\hline Mesic & $0.30 b^{z}$ & $0.30 \mathrm{c}$ & $0.09 \mathrm{~b}$ & $0.70 \mathrm{bc}$ \\
\hline Mixed & $0.22 \mathrm{~d}$ & $0.31 \mathrm{c}$ & $0.09 \mathrm{~b}$ & $0.61 \mathrm{~d}$ \\
\hline Xeric & $0.29 \mathrm{c}$ & $0.29 \mathrm{~cd}$ & $0.08 \mathrm{~b}$ & $0.66 \mathrm{~cd}$ \\
\hline \multicolumn{5}{|l|}{2010} \\
\hline Mesic & $0.38 \mathrm{a}$ & $0.36 \mathrm{~b}$ & $0.09 \mathrm{~b}$ & $0.82 \mathrm{a}$ \\
\hline Mixed & $0.22 \mathrm{~d}$ & $0.40 \mathrm{a}$ & $0.11 \mathrm{a}$ & $0.74 b$ \\
\hline Xeric & $0.35 \mathrm{ab}$ & $0.27 \mathrm{~d}$ & $0.09 \mathrm{~b}$ & $0.71 \mathrm{bc}$ \\
\hline
\end{tabular}

${ }^{2}$ Means within a column not followed by same letter are different at $P \leq 0.05$.

xeric landscape had lesser $\mathrm{K}_{1}$ in 2010. Landscape factors can be used as a tool in irrigation decision-making, which could contribute to water savings in amenity landscapes (Pannkuk et al., 2010). Few $\mathrm{K}_{1}$ values have been reported, although Pannkuk et al. (2010) reported $\mathrm{K}_{1}$ of St. Augustine grass ranged from 0.45 to 0.62 , seasonally, and for mixed-species landscapes ranged from 0.5 to 0.7 in southern Texas. Landscape factors for complete landscapes, including woody plants, turf, and perennials, have not been previously reported. Therefore, $\mathrm{K}_{1}$ values developed under well-watered conditions in this study may provide guidelines as exploratory standards in allocating landscape irrigation water in the IMW region.

This study suggests classifying plants by type (height) or water use may not be useful for estimating water demand and irrigation management of water-efficient landscaping. Absence of $\mathrm{K}_{\mathrm{p}}$ differences among plant water use categorizations indicates that the perception of drought-tolerant plants being low water use plants needs to be clarified. For example, woody and perennial species in this study categorized as low water use from aridxeric habitats consumed almost as much water as mesic plants under well-watered conditions, differing only by canopy cover fraction (Fig. 6). High water use rates in plants from dry habitats are not surprising, because many have deep roots to forestall water stress, but many also have shallow roots for scavenging surface water from unpredictable summer rain. Pinus edulis, used in this study and widespread in the IMW, has been shown to respond to shallow surface watering in addition to deep roots to tolerate drought characteristics of the region (West et al., 2007). The same mechanism appears to apply to tall fescue used in this study. So the three putative water use classifications-mesic, mixed, xeric - are perhaps better described as differences in drought tolerance or minimum water need classifications. Ability to tolerate low soil water conditions varies widely among species and may be considered as a drought tolerance rating, meaning minimum level of plant water needed to achieve an acceptable appearance in a landscape. Therefore, managing water-efficient landscapes under certain levels of water stress may be possible while maintaining an acceptable appearance as well as achieving the objective of water conservation in landscapes because appropriate species are able to tolerate low soil water conditions (Montague et al., 2004; Reid and Oki, 2008). An advantage of water-efficient landscaping irrigated at minimum water needs is a reduction of luxury water use. Because ornamental landscapes are valued for their appearance rather than growth or yield, maximum well-watered irrigation and resultant luxury plant water use may result in greater vegetative growth and, consequently, more pruning and mowing, increasing labor as well as water costs. Another benefit of irrigating to minimum water needs for more xeric plants is encouraging deeper rooting and exploiting a greater volume of soil water during dry periods.

The trend (Fig. 6) indicating similar turf and non-turf $\mathrm{K}_{\mathrm{p}}$ at well-watered, full canopy cover suggests that assigning different $K_{p}$ values to non-turf landscape plants based on type varying by height (tree, shrub, groundcover) is probably not a meaningful distinction in water-efficient landscaping. Similar well-watered, full canopy water use rates between woody and turf plants are likely a tradeoff between boundary layer and stomatal limitations. Woody plant zones in this study presented a rough (variable height), well-ventilated canopy closely coupled to atmosphere (Seraphin and Guyenne, 2008), even the near complete canopy cover mesic zone, when compared with turf. Consequently, high vapor deficits characteristic of arid regions (Gao et al., 2005) imposed at the leaf level (Jarvis, 1985) typically trigger stomatal closure (Turner et al., 1984) that increases with even small changes in plant height (Medeiros and Pockman, 2010). Stomatal sensitivity to vapor deficits is common in woody plants, moderating transpiration rates (Choudhury and Monteith, 1986) when leaf area indices (LAIs) are similar to turf (Pereira et al., 2007). Although woody plant canopies can reach high LAI (Schleppi et al., 2011), up to twice that of turf (Pereira et al., 2007 ), ventilation and stomatal sensitivity to vapor deficits also increases with height (Ambrose et al., 2010), again moderating transpiration rates (Choudhury and Monteith, 1986). The tradeoff is that turfgrass may have high stomatal conductance rates but overall canopy transpiration is limited by low boundary layer conductance (Jarvis, 1985).

A potentially more meaningful distinction would be adjusting $\mathrm{K}_{\mathrm{p}}$ values based on canopy cover (Fig. 6). Intuitively, water loss decreases if the number of transpiring leaves decreases within a given area such as an irrigation zone. Figure 6 indicates $K_{p}$ can be adjusted downward almost at a 1:1 basis as percent cover decreases, and sprinkler irrigation application frequency can be adjusted accordingly. Below 50\% canopy cover, drip/low volume irrigation is a more water-efficient choice where number of leaves would also be the primary driver of water needed by an individual plant relative to $\mathrm{K}_{\mathrm{p}}$.

Modification of $\mathrm{K}_{\mathrm{p}}$ by canopy cover and drought tolerance rating should lead to downward adjustment of well-watered $\mathrm{K}_{\mathrm{p}}$ in landscape irrigation zones of mixed plant types. This would enable landscape managers and designers to achieve greater water conservation when there is reduced canopy cover, low plant densities, and plants have known drought tolerance abilities. This approach appears feasible based on our findings and those reported under water-limiting conditions (Pittenger and Henry, 2005; Reid and Oki, 2008; Shaw and Pittenger, 2004). Plants with greater drought tolerance, or lower water need ratings, may be of importance for use in water-efficient landscaping. A turf $\mathrm{K}_{\mathrm{p}}$ with a common $100 \%$ plant cover would be controlled by turf drought tolerance abilities. For non-turf plants, however, canopy cover appears to be the controlling factor of water use under well-watered conditions. $\mathrm{K}_{\mathrm{p}}$ is a function of canopy cover fraction, so the value of $K_{p}$ could be reduced by some function of canopy cover and species minimum water need rating. The percent reduction of $\mathrm{K}_{\mathrm{p}}$ for a non-turf plant zone could be roughly estimated visually by a landscape manager based on canopy cover and plant drought tolerance classifications, but minimum water needs would have to be carefully evaluated at the design stage, and mixing species of different minimum water needs would limit water conservation potential. A percentage reduction in zone $\mathrm{K}_{\mathrm{p}}$ value, programmed into smart irrigation controllers or station run times, could be adjusted by irrigation managers using the global percentage function present in most irrigation controllers.

\section{Conclusions}

Under the well-watered conditions of this study, we determined plant canopy cover - rather than plant material water use categorization-was the controlling factor in woody plant and perennial water use. This suggests that categorizing water use based on plant type, as suggested by the Environmental Protection Agency (EPA Water Sense, 2009) appears to have no merit. Consequently, landscape managers may achieve meaningful water savings by simply adjusting landscape-planting densities. In the meantime, adjusting percentage of landscape area devoted to woody plants, turf, and perennials based on $K_{p}$ and adjusted $K_{p}$ of each hydrozone may provide another method for conserving water in landscapes under well-watered conditions. The $\mathrm{K}_{\mathrm{p}}$ values and irrigation timings for different plant types developed from this study may also serve as a guideline for setting well-watered irrigation schedules in the IMW region. Under waterstressed conditions, however, plant material choice will likely play a more central role in overall landscape water use. Plants with greater drought tolerance, or lower water need ratings, may be of importance for use in water-efficient landscaping. The results of this study also suggest that mild water stress promotes water uptake deeper in the root zone, particularly for drought-adapted plants 
that have opportunistic water uptake patterns. Further research on water-stressed conditions is needed to ascertain drought tolerance for different plant types under different minimum water demand categorizations.

\section{Literature Cited}

Allen, R.G., R. Walter, R. Elliot, and T. Howell. 2005a. The ASCE standardized reference evapotranspiration equation. Amer. Soc. Civil Eng., Reston, VA.

Allen, R.G., L.S. Pereira, M. Smith, D. Raes, and J.L. Wright. 2005b. FAO-56 dual crop coefficient method for estimating evaporation from soil and application extensions. J. Irr. and Drainage Eng.-Asce 131:2-13.

Ambrose, A.R., S.C. Sillett, G.W. Koch, R. van Pelt, M.E. Antoine, T.E. Dawson, and F. Meinzer. 2010. Effects of height on treetop transpiration and stomatal conductance in coast redwood (Sequoia sempervirens). Tree Physiol. 30:1260-1272.

Aronson, L.J., A.J. Gold, R.J. Hull, and J.L. Cisar. 1987. Evapotranspiration of cool-season turfgrasses in the humid Northeast. Agron. J. 79:901-905.

Beeson, R.C. 2005. Modeling irrigation requirements for landscape ornamentals. HortTechnology 15:18-22.

Blonquist, J.M., S.B. Jones, and D.A. Robinson. 2006. Precise irrigation scheduling for turfgrass using a subsurface electromagnetic soil moisture sensor. Agr. Water Mgt. 84:153-165.

Bos, M.G., R.A.L. Kselik, R.G. Allen, and D. Molden. 2008. Water Requirements for Irrigation and the environment. 1st Ed. Springer, New York, NY.

Brown, P. and D. Kopec. 2000. Converting reference evapotranspiration into turf water use. Turf Irrigation Management Series II, The University of Arizona. 7 Mar. 2011. <http:// ag.arizona.edu/pubs/water/az1195.pdf>.

Brown, P.W., C.F. Mancino, M.H. Young, T.L. Thompson, P.J. Wierenga, and D.M. Kopec. 2001. Penman Monteith crop coefficients for use with desert turf systems. Crop Sci. 41:1197-1206.

Buwalda, J.G. and F. Lenz. 1995. Water-use by European pear trees growing in drainage lysimeters. J. Hort. Sci. 70:531-540.

Carrow, R.N. 1995. Drought resistance aspects of turfgrasses in the Southeast-Evapotranspiration and crop coefficients. Crop Sci. 35:1685-1690.

Carrow, R.N. 1996. Drought avoidance characteristics of diverse tall fescue cultivars. Crop Sci. 36:371-377.

Choudhury, B. and J. Monteith. 1986. Implications of stomatal response to saturation deficit for the heat balance of vegetation. Agr. Meteorol. 36:215-225.

Costello, L.R., N.P. Matheny, and J.R. Clark. 2000. The landscape coefficient method. In: A guide to estimating irrigation water needs of landscape planting in California. University of California Cooperative Extension, California Department of Water Resources, Sacramento, CA. $<$ http://www.water.ca.gov/wateruseefficiency/ docs/wucols00.pdf>.

Cuenca, R.H. 1989. Irrigation system design. Prentice Hall, Englewood, NJ.

Devitt, D.A. and R.L. Morris. 2008. Urban landscape water conservation and the species effect, p. 171-192. In: Beard, J.B. and M.P. Kenna. Water quality and quantity issues for turfgrasses in urban landscapes. The Council for Agricultural Science and Technology, Ames, IA.

Devitt, D.A., R.L. Morris, and D.C. Bowman. 1992. Evapotransportation, crop coefficients, and leaching fractions of irrigated desert turfgrass systems. Agron. J. 84:717-723.

Eching, S. and R.L. Snyder. 2005. Estimating urban landscape evapotranspiration. In: Walton, $\mathrm{R}$. (ed.). Impacts of global climate change: World Water and Environmental Resources Congress, Anchorage, AK. 15-19 May. <http://cedb.asce. org/cgi/WWWdisplay.cgi?147023>.

EPA WaterSense. 2009. WaterSense water budget approach. Environmental Protection Agency. 11 Mar. 2011. <http://www.epa.gov/WaterSense/ docs/ws_water_budget_approach508.pdf > .

Ervin, E.H. and A.J. Koski. 1998. Drought avoidance aspects and crop coefficients of kentucky bluegrass and tall fescue turfs in the semiarid west. Crop Sci. 38:788-795.

Fry, J.D. and J.D. Butler. 1989. Responses of tall and hard fescue to deficit irrigation. Crop Sci. 29:1536-1541.

Gao, Q., M. Yu, X. Zhang, H. Xu, and Y. Huang. 2005. Modelling seasonal and diurnal dynamics of stomatal conductance of plants in a semiarid environment. Funct. Plant Biol. 32:583-598.

Jarvis, P. 1985. Coupling of transpiration to the atmosphere in horticultural crops: The Omega Factor. Acta Hort. 171:187-206.

Jia, X.H., M.D. Dukes, and J.M. Jacobs. 2009. Bahiagrass crop coefficients from eddy correlation measurements in central Florida. Irrig. Sci. 28:5-15.

Kjelgren, R., T. Montague, and R. Beeson. 2005. Water use and stomatal behavior of sweetgum (Liquidambar styraciflua L.) relative to reference evaporation in three contrasting regions. Acta Hort. 664:353-360.

Kjelgren, R., L. Rupp, and D. Kilgren. 2000. Water conservation in urban landscapes. HortScience 35:1037-1040.

Kopec, D.M., R.C. Shearman, and T.P. Riordan. 1988. Evapotranspiration of tall fescue turf. HortScience 23:300-301.

Medeiros, J.S. and W.T. Pockman. 2010. Carbon gain and hydraulic limits on water use differ between size classes of Larrea tridentata. J. Arid Environ. 74:1121-1129.

Moller, A.L. and R.R. Gillies. 2008. Utah climate. 2nd Rd. USU Press, Logan, UT.

Montague, T., R. Kjelgren, R. Allen, and D. Wester. 2004. Water loss estimates for five recently transplanted landscape tree species in a semiarid climate. J. Environ. Hort. 22:189-196.

Pannkuk, T.R., R.H. White, K. Steinke, J.A. Aitkenhead-Peterson, D.R. Chalmers, and J.C. Thomas. 2010. Landscape coefficients for singleand mixed-species landscapes. HortScience 45:1529-1533.

Pereira, A.R., S.R. Green, and N.A.V. Nova. 2007. Sap flow, leaf area, net radiation and the Priestley-Taylor formula for irrigated orchards and isolated trees. Agr. Water Mgt. 92:48-52.

Pittenger, D. and J.M. Henry. 2005. Refinement of urban landscape water requirements. University of California Cooperative Extension, Central Coast \& South Region. 10 Mar. 2011. $<$ http://groups.ucanr.org/CLUH/files/25773. pdf $>$.

Reid, S.K. and L.R. Oki. 2008. Field trials identify more native plants suited to urban landscaping. Calif. Agr. 62:97-104.

Sachs, R.M., T. Kretchun, and T. Mock. 1975. Minimum irrigation requirements for landscape plants. J. Amer. Soc. Hort. Sci. 100:499-502.
Salo, C., R. Unnasch, and C. Wisnewski. 2008. Measuring vegetation with line-point intercept and line intercept methods. Sound Science White paper Series \#3. 10 Mar. 2011. <http:// www.sound-science.org/S2WhitePaper03LPI. pdf $>$.

Schleppi, P., A. Thimonier, and L. Walthert. 2011. Estimating leaf area index of mature temperate forests using regressions on site and vegetation data. For. Ecol. Mgt. 261:601-610.

Seraphin, A. and P. Guyenne. 2008. A flume experiment on the adjustment of the mean and turbulent statistics to a transition from short to tall sparse canopies. Boundary-Layer Meteorol. 129:47-64.

Shaw, D.A. and D.R. Pittenger. 2004. Performance of landscape ornamentals given irrigation treatments based on reference evapotranspiration. Acta Hort. 664:607-614.

Smith, C.S. and R. St. Hilaire. 1999. Xeriscaping in the urban environment, p. 241-250. In: Herrera, E.H. and J.G. Mexal (eds.). Ensuring sustainable development of arid lands. New Mexico J. Sci. 38. New Mexico Acad. Sci., Albuquerque, NM.

Sovocool, K.A., M. Morgan, and D. Bennett. 2006. An in-depth investigation of Xeriscape as a water conservation measure. J. Amer. Water Works Assn. 98:82-93.

St. Hilaire, R., M.A. Arnold, D.C. Wilkerson, D.A. Devitt, B.H. Hurd, B.J. Lesikar, V.I. Lohr, C.A. Martin, G.V. McDonald, R.L. Morris, D.R. Pittenger, D.A. Shaw, and D.F. Zoldoske. 2008. Efficient water use in residential urban landscapes. HortScience 43:2081-2092.

Stewart, J.R., R. Kjelgren, P.G. Johnson, and M.R. Kuhns. 2004. Soil-water-use characteristics of precision-irrigated buffalograss and Kentucky bluegrass. Online. Applied Turfgrass Sci. DOI:10.1094/ATS-2004-111801-RS.

Tennant, D. 1975. A test of modified line intersect method of estimating root length. J. Ecol. 63:995-1001.

Turner, N., E. Schulze, and T. Gollan. 1984. The responses of stomata and leaf gas exchange to vapour pressure deficits and soil water content. Oecologia 63:338-342.

United States Department of Agriculture. 1968. Soil survey: Davis-Weber area, Utah. US Printing Office, Washington, DC.

Utah Division of Water Resources. 2003. Utah's M\&I water conservation plan: Investing in the future. 21 Feburary 2011. <http://www.water. utah.gov/M\&I/plan7-14-03.pdf >

van Genuchten, M.T. 1980. A closed-form equation for prediction the hydraulic conductivity of unsaturated soils. Soil Sci. Soc. Amer. J. 44:892-898.

Water Use Efficiency Branch. 2009. Model water efficient landscape ordinance: Senate Bill SBx7-7. California Dept. Water Resources. 21 Jan. 2011. $<\mathrm{http}: / /$ www.water.ca.gov/wateruseefficiency/ $\mathrm{sb} 7 />$.

West, A.G., K.R. Hultine, T.L. Jackson, and J.R. Ehlerninger. 2007. Differential summer water use by Pinus edulis and Juniperus osteosperma reflects contrasting hydraulic characteristics. Tree Physiol. 27:1711-1720.

White, R., R. Havlak, J. Nations, T.R. Pannkuk, J.C. Thomas, D.R. Chalmers, and D. Dewey. 2004. How much water is 'enough'? Using PET to develop water budgets for residential landscapes. TX Water Resources Institute TR271, College Station, TX. 